\title{
Continuous Photometric Measurement of Lipase Activity with the Substrate Triolein
}

\author{
By G. HILlmanN and G. WeIdemanN \\ Chemisches Institut der Städt. Krankenanstalten Nürnberg
}

(Eingegangen am 26. April 1973)

Herrn Prof. Dr. Dr. Ernst Schütte qum 65. Geburtstag gewidmet

\begin{abstract}
Triolein (free from oleic acid) is emulsified in a solution of calcium $m$-nitrophenolate with the aid of Thesit or Sterox-SE. As a measure of enzyme activity, the decrease in extinction in the emulsion, which is proportional to the hydrogen ion concentration, is measured continuously at $436 \mathrm{~nm}$ with a light path of $0.5 \mathrm{~cm}$. The reaction temperature is $25^{\circ} \mathrm{C}$ and the time of measurement is 10 min. The determination is performed as a single reagent test on the microlitre scale. The normal range of serum lipase activity lies within the methodical error $(<50 \mathrm{U} / \mathrm{l})$.
\end{abstract}

Triolein (ölsäurefrei) wird mit Thesit oder Sterox-SE in einer Lösung von Calcium-m-nitrophenolat emulgiert. Die der Wasserstoffionenkonzentration proportionale Extinktionsabnahme in der Emulsion wird bei $436 \mathrm{~nm}$ und $0,5 \mathrm{~cm}$ Schichttiefe als Maß der Enzymaktivität fortlaufend registriert. Die Meßtemperatur beträgt $25^{\circ} \mathrm{C}$, die Meßzeit $10 \mathrm{~min}$. Der Bestimmungsansatz wird im Ein-Reagenz-Test als Mikrolitermethode durchgeführt. Der Normbereich der Serumlipaseaktivität liegt innerhalb des methodischen Fehlers ( $<50$ U/l).

Three essential factors must be considered in the determination of lipase activity: the choice of substrate, the production of an optimal surface area by emulsification and the measurement of the rate of hydrolysis. In contrast to the commercial product olive oil, triolein is a chemically well defined substrate of highest specifity (1). Large amounts of liquid triglyceride are necessary to produce an optimal surface area by the convenient method of emulsifying with highly concentrated solutions of gum arabic, the latter being an ill-defined polysaccharide containing ester groups (2). The continuous measurement of lipase activity in a kinetic assay has been performed by electrometric titration of the hydrogen ions liberated during incubation with emulsified olive oil at $\mathrm{pH} 8.6$ (3). The discontinuous photometric measurement of the fatty acid-copper-complex, following enzymatic hydrolysis, is well known (4). A nephelometric determination in a kinetic assay has been described recently (5). We have developed a new method.

\section{Principle}

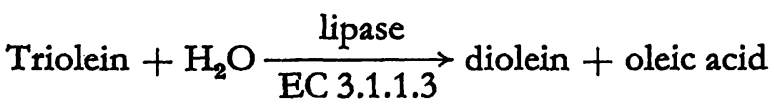

oleic acid + calcium- $m$-nitrophenolate $\rightarrow$ calcium oleate $+m$-nitrophenol

The new method is based on the following concept: Changes in the absorbance of a suitable buffer-indicatorsystem, emulsified with triolein, should be equivalent to the hydrogen ions liberated during specific enzymatic hydrolysis and measurable by modern spectrophotometers. $m$-Nitrophenol is the only known indicator that is also capable of acting as a buffer substance at $\mathrm{pH}$ 8.6-8.4. Lipase-activity is activated by calcium ions (6). By the use of calcium $m$-nitrophenolate, the decrease of absorbance, measured at $436 \mathrm{~nm}$, is proportional to the amount of liberated oleic acid. To avoid unspecific hydrolysis, a new emulsification procedure has been developed. The nonionic and nonhydrolysable detergents Sterox-SE or Thesit have been shown to yield optimal emulsification at certain concentrations. The emulsifying effect of these synthetic substances, commercially available in high purity, is comparable with that of cholic acids. Triolein must be completely free from oleic acid. This is the most important factor in the determination. The reproducibility of the yellow emulsion, made by vigorous mechanical shaking, is monitored photometrically. The kinetic assay is performed in microcuvettes $d=0,5 \mathrm{~cm}$ analogous to those used in single reagent tests, and the results are plotted on a chart recorder during $10 \mathrm{~min}$. It is not possible to compare the accuracy of this determination of lipase activity with that of other methods; it is monitored with the aid of standard enzyme preparations.

\section{Materials and Methods}

Equipment

Spectrophotometer with photomultiplier-recorder-constant temperature cuvette housing (C. Zeiss-Oberkochen, EppendorfHamburg, Vitatron MPS-Düren are suitable). pH-meter with glass- 
electrode. Waterbath, constant temperature $25^{\circ} \mathrm{C}$. Shaking devices (frequency of oscillations about $200 / \mathrm{min}$ ). Glass-cylinders with stoppers, capacity $25 \mathrm{ml}$.

\section{Reagents}

1. Triolein ( $95 \%$, Serva-Heidelberg) is purified by Silicagel $G$ (Merck, Typ 60). $5 \mathrm{~g}$ Triolein are shaken vigorously with $0.5 \mathrm{~g}$ Silicagel $G$ for one hour, and used after sedimentation or centrifugation. Stable about 6 months, kept at $0^{\circ} \mathrm{C}$.

2. Calcium hydroxide, in $\mathrm{H}_{2} \mathrm{O}$ saturated (ca. $0.013 \mathrm{mmol} / \mathrm{l}$ ) Merck $5 \mathrm{~g} \mathrm{Ca}(\mathrm{OH})_{2}$ are shaken vigorously with $1000 \mathrm{ml} \mathrm{H}_{2} \mathrm{O}$ (dist.). Solution is used after sedimentation. Stable about 3 months.

3. Calcium $m$-nittophenolate $(2.2 \mathrm{mmol} / 1, \mathrm{pH} 9) .0 .157 \mathrm{~g} m$-nitrophenol (Merck) are dissolved in $400 \mathrm{ml} \mathrm{H}$ O (dist.) with addition of $30 \mathrm{ml}$ calcium hydroxide solution. $\mathrm{pH} 9$ (glass electrode) is achieved by the further addition of $\mathrm{Ca}(\mathrm{OH})_{2}$ solution and filled the solution is adjusted to $500 \mathrm{ml}$ with $\mathrm{H}_{2} \mathrm{O}$. $(\mathrm{E}=1.49, \mathrm{~d}=1 \mathrm{~cm}$, $436 \mathrm{~nm}$ ). The $\mathrm{pH}$ is checked daily; it decreases by the absorption of $\mathrm{CO}_{2}$ and it may be corrected by the addition of $\mathrm{Ca}(\mathrm{OH})_{2}$ solution.

4. Sterox-SE (Polyoxyethylene-thio-ether) $10 \mathrm{~g} / 1 \mathrm{H}_{2} \mathrm{O}$ (unlimited stability) Harleco, Philadelphia USA, Asid-München.

Thesit (Oxyäthoxydodecan) $10 \mathrm{~g} / 1 \quad \mathrm{H}_{2} \mathrm{O}$ (unlimited stability) Klincke-Hamburg.

5. Substrate Emulsion ( $10 \mathrm{mmol} / \mathrm{l}) .10 \mathrm{ml}$ Calcium $m$-nitrophenolate solution are emulsified with $0.1 \mathrm{ml}$ Triolein by the addition of 0.2 $\mathrm{ml}$ Thesit or Sterox-SE (both detergents are equivalent) and shaking mechanically for at least 1 hour in tightly stoppered glass cylinders. The time necessary for optimal emulsification is related to the frequency of oscillations and it depends on the shaking apparatus used. Rotating mixers and sonic vibrators have been proved unsuitable. The glass cylinders are rinsed repeatedly with calcium $m$-nitrophenolate solution before use. During emulsification, $\mathrm{pH}$ decreases from 9 to 8.6 mainly due to absorption of $\mathrm{CO}_{2}$. The emulsification process is monitored photometrically and acidimetrically $(\mathrm{d}=0.5 \mathrm{~cm}, 436 \mathrm{~nm})$. The yellow emulsion is kept at $25^{\circ} \mathrm{C}$ tightly closed. Stability about 10 hours.

6. Enzyme Standard (Versatol-E. Goedecke-Berlin, Warner Lambert, Morris Plains, N. J. USA).

\section{Procedure}

Pipette into microcuvettes (carefully cleaned and free from acid) $\mathrm{d}=0.5 \mathrm{~cm}$

$\begin{array}{ll}\text { Substrate-Emulsion } & 1 \mathrm{ml} \\ \text { Serum } & 0.02 \mathrm{ml}\end{array}$

mix, allow $1 \mathrm{~min}$ to equilibrate and scan $(0.5 \mathrm{~cm} / \mathrm{min})$ at $436 \mathrm{~nm}$ for $10 \mathrm{~min}$ to obtain the absorbance change per min. Pancreatic juice is diluted with serum (without lipase-activity) in an appropriate ratio.

Assay concentrations (optimised conditions):

\begin{tabular}{|c|c|}
\hline Triolein & $10 \mathrm{mmol} / 1$ (Emulsion) \\
\hline Calcium $^{2+}$ & $0.9 \mathrm{mmol} / 1$ \\
\hline$m$-nitrophenol & $2.2 \mathrm{mmol} / 1$ \\
\hline Thesit (Sterox-SE) & $0.2 \mathrm{~g} / 1$ \\
\hline $\mathrm{pH}$ & 8.6 \\
\hline Temperature & $25^{\circ} \mathrm{C}$ \\
\hline
\end{tabular}

The reaction rate is linear for $4 \mathrm{~min}$ with activities up to $500 \mathrm{U} / 1$ sample.

\section{Calculations}

Absorbance change after the addition of $0.2 \mu \mathrm{mol} \mathrm{H}^{+}$ under assay conditions $(\mathrm{pH}=8.6, \mathrm{~d}=0.5,436 \mathrm{~nm})$ $\Delta \mathrm{E}=0.185$ ( $\mathrm{pH}$ decreases from $\mathrm{pH} 8.6$ to 8.4 ) Volumeactivity $\Delta \mathrm{E} / \mathrm{min} \cdot 53000=\mathrm{U} / \mathrm{l}$.

\section{Precision}

$\overline{\mathrm{x}} \pm \mathrm{s}$ (series, $\mathrm{n}=20)=185 \pm 20 \mathrm{U} / 1 \mathrm{VK}=10.8 \%$ $\overline{\mathrm{x}} \pm \mathrm{s}$ (day to day/Versatol-E, $\mathrm{n}=30$ ) $310 \pm 40 \mathrm{U} / 1$ $\mathrm{VK}=12.8 \%$

Normal range $(n=100)=$ up to $50 \mathrm{U} / \mathrm{l}$

\section{References}

1. Rick, W. (1970), Internist 11, 110-117. - 2. Desnuelle, P. \& Savary, P. (1963), J. Lipid. Research 4, 369-384. - 3. Rick, W. (1969), diese Z. 7, 530-539. - 4. SchMIDt, F. H., Stork, H., von DAHL, K. \& Bergmeyer, H. U. (1970), Methoden der enzy- matischen Analyse, Verlag Chemie, Weinheim, 786-791. 5. Zinterhofer, L., WardLaW, ST., JatLOW, P. \& Seligson, D. (1973), Clin. Chim. Acta 44, 173-178. - 6. Benzonana, G. \& Desnuelle, P. (1965), Biochim. Biophys. Acta, 105, 121-123.

Professor Dr. G. Hillmann 85 Nürnberg

Flurstraße 17 